\title{
Pengaruh Religiusitas, Integritas, dan Penegakan Peraturan Terhadap Fraud pada Pengelolaan Keuangan Desa
}

\author{
Made Feri Cahyadi ${ }^{\star}$, Edy Sujana \\ Universitas Pendidikan Ganesha, Singaraja, Bali, Indonesia \\ *madefericahyadi@gmail.com
}

Riwayat Artikel:

Tanggal diajukan:

26 Juni 2020

Tanggal diterima:

25 Agustus 2020

Tanggal dipublikasi:

31 Agustus 2020

\begin{abstract}
Abstrak
Tujuan dari penelitian ini yakni mengetahui pengaruh religiusitas, integritas, dan penegakan peraturan terhadap fraud pada pengelolaan keuangan desa di Kabupaten Buleleng. Pendekatan kuantitatif digunakan pada penelitian ini dengan menjadikan kuesioner berskala likert sebagai data primer. Populasi yang digunakan yakni perangkat desa yang terdiri dari Kepala Desa, Sekretaris Desa, dan Kaur Keuangan dengan total jumlah populasi secara keseluruhan yaitu 387 perangkat desa di Kabupaten Buleleng. Metode pengambilan sampel yang digunakan adalah metode probability sampling yaitu teknik proportional random sampling dengan responden sebanyak 168 responden. Analisis regresi linier berganda dengan bantuan SPSS 24.0 for Windows digunakan untuk mengolah perolehan data. Setelah dilakukan pengujian, ditemukan bahwa fraud pada pengelolaan keuangan desa dipengaruhi secara negative dan signifikan oleh variabel religiusitas $\left(X_{1}\right)$, variabel integritas $\left(X_{2}\right)$, dan variabel penegakan peraturan $\left(X_{3}\right)$.
\end{abstract}

Kata kunci: religiusitas, integritas, penegakan peraturan, fraud pada pengelolaan keuangan desa

\section{Pengutipan:}

Cahyadi, M. F., \& Sujana, E. (2020). Pengaruh Religiusitas, Integritas, dan Penegakan Peraturan terhadap Fraud pada Pengelolaan Keuangan Desa. Jurnal IImiah Akuntansi dan Humanika, 10 (2), 136-145

Keywords: religiosity, integrity, enforcement regulation, fraud in village financial management

\begin{abstract}
The purpose of this study was to find out the effect of religiosity, integrity, and enforcement of regulations toward fraud in village financial management in Buleleng Regency. This study used quantitative approach which was using primary data sources that was obtained through questionnaires and measured with a Likert scale. The functionary village consisting of the Headman, Secretary, and the Head of Finance with the total population of 387 functionary village in Buleleng Regency were chosen as the population of this study. The sampling was the probability sampling method that was proportional random sampling technique with 168 respondents. The obtained data were processed using multiple linear regression analysis method with the support of SPSS 24.0 for Windows. After being tested, it was found that the fraud in village financial management was affected by the religiosity variable $\left(X_{1}\right)$, the integrity variable $\left(X_{2}\right)$, and the enforcement regulation variable $\left(X_{3}\right)$.
\end{abstract}

\section{Pendahuluan}

Desa merupakan bagian terkecil dari unit organisasi pemerintah daerah yang berhadapan secara langsung dengan masyarakat. Desa memiliki wewenang dalam melaksanakan dan mengontrol pemerintahan serta berbagai kepentingan masyarakatnya. Dalam mengatur dan mengurus rumah tangga, tentunya desa sebagai suatu organisasi memerlukan sumber keuangan atau pendapatan untuk menjalankan berbagai program yang dapat memajukan wilayah pedesaan. Salah satu sumber pendapatan desa menurut Peraturan Menteri Dalam Negeri Nomor 20 Tahun 2018 adalah pendapatan transfer meliputi dana desa yang bersumber dari APBN, bagi hasil pajak daerah kabupaten/kota dan retribusi 
daerah, Alokasi Dana Desa (ADD), serta bantuan keuangan APBD pemerintah provinsi dan kabupaten/kota.

Kabupaten Buleleng yang mempunyai 129 desa menjadikannya kabupaten terluas di Provinsi Bali. Sumber-sumber pendapatan desa di Kabupaten Buleleng yang dikirimkan oleh pemerintah pusat seperti dana desa sesuai anggaran APBN serta pendapatan dari pemerintah daerah berupa retribusi daerah, pajak daerah, serta sekurang-kurangnya $10 \%$ total Dana Alokasi Umum (DAU) dan Dana Bagi Hasil (DBH) yang merupakan pendanaan dari Anggaran Pendapatan dan Belanja Daerah (APBD) dan kerap diistilahkan dengan Alokasi Dana Desa (ADD). Ditinjau dari perolehan data Dinas Pemberdayaan Masyarakat dan Desa Kabupaten Buleleng, total pendapatan yang diterima seluruh kecamatan yang ada di Kabupaten Buleleng cukup tinggi yaitu sebesar Rp 241.778.738.000 (bulelengkab.go.id/).

Tingginya nominal penerimaan yang diperoleh desa akan berimplikasi pada besarnya tanggung jawab yang dipangku oleh aparatur pemerintah desa sebagai pihak pengelola pendapatan desa. Pengelolaan keuangan desa dalam beberapa kondisi sangat riskan terhadap tindak kecurangan (fraud) yang dilakukan oleh pengelola keuangan desa. Fraud merupakan perilaku melawan hukum atau aturan yang dilakukan oleh individu ataupun kelompok baik secara sengaja maupun tidak sengaja dengan tujuan untuk memperoleh keuntungan pribadi atau kelompok berupa harta benda, uang dan lainnya yang membuat pihak lain dirugikan (Aini et al., 2017). Menurut Indonesia Corruption Watch (ICW), beberapa titik yang rawan terhadap terjadinya kecurangan meliputi proses saat direncanakan, proses saat dilaksanakan, proses saat disediakannya barang dan jasa, proses dalam bertanggung jawab, serta proses saat memantau dan mengevaluasi. Tindakan kecurangan (fraud) dapat dikategorikan menjadi tiga yang terdiri dari korupsi (corruption), kecuranganlaporan keuangan (fraudulent financial statement), dan penyalahgunaan aset (asset misappropriation).

Terjadinya kecurangan pada pengelolaan keuangan desa dapat dilihat dari berbagai kasus yang dilakukan oleh perangkat desa di beberapa desa di Kabupaten Buleleng. Perbekel Desa Dencarik Kecamatan Banjar ditetapkan sebagai tersangka pada atas dugaan kasus korupsi dana APBDes. Perangkat Desa Tirtasari Kecamatan Banjar melakukan penyalahgunaan dana anggaran finishing Kantor Desa dan penyelewengan juga terjadi pada laporan pertanggungjawaban APBDesa Tirtasari (Bali Editor, 2019). Perbekel Desa Banjar Kecamatan Banjar telah melakukan penyalahgunaan dana Bantuan Keuangan Khusus (BKK) dimana Perbekel Desa Banjar melaksanakan kegiatan tidak sesuai dengan proposal yang diajukan dengan menggunakan dana BKK tersebut (Kumparan, 2019). Perbekel Desa Celukanbawang Kecamatan Gerokgak melakukan tindakan korupsi karena tidak menyerahkan dana ganti rugi pembangunan Kantor Perbekel baru yang diberikan oleh PT General Energy Bali (PT GEB) (Candra, 2019).

Berdasarkan beberapa informasi tersebut, menunjukkan bahwa beberapa perangkat desa di Kabupaten Buleleng telah melakukan tindak kecurangan pada saat mengelola keuangan desa. Seseorang melakukan suatu tindakan dapat dipengaruhi oleh dua faktor yaitu faktor internal dan faktor eksternal, dimana hal tersebut dijelaskan dalam teori atribusi (Attribution Theory) (K. Y. K. dan N. M. D. R. Dewi, 2017). Begitu pula dengan perilaku kecurangan yang dilakukan individu diakibatkan oleh pengaruh dari dalam dan luar. Faktor internal yang dapat membuat seseorang berperilaku curang yakni dengan religiusitas atau keimanan serta integritas atau kejujuran dalam melaksanakan tanggung jawab. Kurang tegasnya penegakan peraturan menjadi faktor dari luar yang berpotensi mendorong seseorang untuk bertindak curang.

Berdasarkan definisi dari (Pamungkas, 2014), "religiusitas merupakan suatu sistem yang menyatu meliputi kepercayaan, gaya hidup, aktivitas ritual dan institusi yang memberikan arti dalam kehidupan manusia dan mampu mengendalikan manusia agar tetap berada pada nilai-nilai suci atau nilai-nilai tertinggi". Religiusitas juga didefinisikan sebagai pandangan seseorang dari berbagai sisi yang tidak berlaku pada saat beraktivitas ritual (beribadah) saja melainkan kegiatan lainnya yang didukung oleh kekuatan supranatural (Herlyana et al., 2017). 
Religiusitas memberikan pengaruh pada perilaku seseorang dimana dalam kehidupan di masyarakat religiusitas digunakan sebagai norma karena masyarakat percaya bahwa religiusitas mampu mengontrol masyarakat sehingga potensi seseorang bertindak sesuatu yang tidak diperkenankan oleh agama pun dapat diminimalisir (Aida, 2017). Tingginya religiusitas seseorang akan membuat mereka takut untuk bertindak demikian atau kepercayaan karena terdapat kepercayaan bahwa apapun yang dilakukan saat ini akan membuahkan hasil atau karma dari tingkah laku dimana hasil tersebut akan dipetik di kemudian hari bahkan di kehidupan selanjutnya.

Berbagai kasus yang dilakukan aparat desa mencerminkan bahwa perilaku yang buruk seperti kecurangan mampu mengalahkan jiwa religiusitas seseorang. Penelitian yang dilakukan (Herlyana et al., 2017). menyatakan bahwa kecurangan dipengaruh secara negatif dan signifikan oleh religiusitas, yang menandakan tingginya religiusitas seseorang membuat kecurangan akan semakin rendah. Sebaliknya, jika religiusitas seseorang rendah maka kecurangan akan semakin tinggi. Berdasarkan uraian sebelumnya, terbentuk hipotesis pertama yakni:

\section{$\mathrm{H}_{1}$ : Religiusitas Berpengaruh Negatif dan Signifikan Terhadap Fraud pada Pengelolaan Keuangan Desa.}

Integritas juga dapat mengakibatkan seseorang cenderung bertindak curang. Integritas seseorang menunjukkan bahwa ia merupakan orang dengan karakter kuat dan memiliki kepribadian yang jujur. (Mujianingrum, 2019) mendefinisikan integritas sebagai konsistensi komitmen tiap individual pada ideologi yang etis yang dapat dilihat melalui perilaku individu tersebut dalam kehidupan. Integritas menggambarkan konsistensi individu antara tuturan atau ujaran dan keyakinan yang dicerminkan dari perilaku dalam kehidupan sehari-hari. Integritas seorang individu dalam bersikap dan berperilaku dapat dijadikan sebagai tolak ukur dalam menjalankan setiap tugas dan kewajiban yang menjadi tanggung jawabnya.

Integritas menuntut setiap individu agar selalu berbuat jujur dan terbuka, bijaksana, serta berani mempertanggungjawabkan setiap tingkah lakunya. Kasus-kasus kecurangan aparatur pemerintah desa yang terjadi di beberapa desa di Kabupaten Buleleng menggambarkan kegagalan integritas dalam melaksanakan tanggung jawab pengelolaan keuangan desa. Dalam pengelolaan keuangan desa, aparatur pemerintah desa sebagai pihak penanggung jawab penuh seharusnya tidak melakukan tindakan yang bisa mencerminkan kegagalan integritas seorang pemimpin. Integritas yang memprioritaskan pada pelayanan publik merupakan suatu bentuk komitmen perangkat desa untuk memberikan layanan secara optimal kepada masyarakat agar terciptanya tata kelola pemerintahan yang baik (good governance) dan terhindar dari tindakan kecurangan (fraud) (Lestari \& Supadmi, 2017)

(Lestari \& Supadmi, 2017) menemukan adanya pengaruh negatif yang diberikan oleh integritas pada kecurangan akuntansi. Apabila seseorang mempunyai integritas dalam melakukan suatu kegiatan maupun bertindak sehari-hari berdasarkan prinsip yang benar dan etis sesuai dengan nilai dan norma, maka seseorang akan dijauhkan dari kecenderungan untuk bertindak curang. Namun, peningkatan potensi terjadinya kecurangan akan terjadi dengan rendahnya integritas seseorang. Berdasarkan pemaparan tersebut, terbentuk hipotesis kedua, yakni:

\section{$\mathrm{H}_{2}$ : Integritas Berpengaruh Negatif dan Signifikan Terhadap Fraud pada Pengelolaan Keuangan Desa.}

Lemahnya penegakan peraturan dalam organisasi dapat dijadikan celah atau kesempatan oleh seseorang dalam melakukan tindakan kecurangan. Peraturan merupakan sejumlah ikatan yang mengatur seluruh anggota organisasi dan harus dipatuhi selama berjalannya kegiatan operasional sehingga efektivitas serta efisiensi segala aktivitas keorganisasian terjamin. Peraturan di dalam organisasi dapat mengendalikan tingkah laku setiap anggota demi kelancaran semua aktivitas dalam suatu organisasi. Jika penegakan peraturan dalam instansi kurang efektif akan menjadi kesempatan bagi siapa saja untuk 
melakukan pelanggaran pada aturan yang berlaku yang mengarah pada tindakan kecurangan.

Penegakan peraturan merupakan proses diterapkannya berbagai upaya untuk mengimplementasikan norma-norma atau aturan-aturan sebagai kontrol perilaku dalam kehidupan bermasyarakat. Fraud sebagai tindakan yang melanggar aturan perlu dilakukan upaya penegakan peraturan secara konsisten dan berkesinambungan serta pemberian sanksi tegas kepada para pelanggar sehingga perilaku kecurangan dapat berkurang dan tidak terulang kembali (Didi dan Indra Cahya Kusuma, 2018). Kepatuhan semua pihak dalam organisasi terhadap peraturan yang berlaku menjadi sangat penting karena apabila peraturan ditegakkan dengan tegas sebagai mana mestinya maka kesadaran hukum dapat tercapai serta dapat menekan peluang ternyadinya tindak kecurangan (Afsari, 2017).

Penelitian (Budiartini, 2019) menjelaskan bahwa penegakan peraturan berpengaruh negatif signifikan terhadap kecurangan akuntansi. Apabila penegakan peraturan dilakukan dengan baik dan optimal maka perilaku kecurangan akuntansi akan semakin rendah. Sebaliknya, apabila penegakan peraturan tidak dilakukan dengan baik maka dapat meningkatkan kecenderungan kecurangan akuntansi. Berdasarkan uraian tersebut, maka hipotesis yang dapat dirumuskan adalah:

\section{$\mathrm{H}_{3}$ : Penegakan Peraturan Berpengaruh Negatif dan Signifikan Terhadap Fraud pada Pengelolaan Keuangan Desa.}

\section{Metode}

Jenis penelitian yang digunakan adalah penelitian pendekatan kuantitatif. Variabel yang digunakan dalam penelitian ini yaitu religiusitas, integritas, penegakan peraturan, dan fraud pada pengelolaan keuangan desa. Sejumlah 387 perangkat desa di Kabupaten Buleleng yang bertanggung jawab dalam pengelolaan keuangan meliputi Kepala Desa, Sekretaris Desa, dan Kepala Urusan (Kaur) Keuangan dipilih sebagai populasi penelitian. Sampel diambil melalui metode probability sampling khususnya proportional random sampling dimana seluruh unsur populasi berkesempatan sama dalam memilih secara acak serta pengambilannya dilakukan dengan proporsional. Secara keseluruhan responden berjumlah 166 orang.

Adapun data primer dan sekunder yang dijadikan sebagai sumber data penelitian ini. Perolehan data primer berasal dari kuesioner pihak lain mengenai religiusitas, integritas, penegakan peraturan, dan fraud pada pengelolaan keuangan desa. Melalui media perantara, didapatkan data sekunder berupa nama-nama desa di Kabupaten Buleleng yang mendapatkan dana desa beserta dana yang dialokasikan untuk desa, hasil pajak yang dibagi dan perolehan retribusi daerah setiap desa dari Dinas Pemberdayaan Masyarakat dan Desa Kabupaten Buleleng.

Kuesioner digunakan sebagai metode dalam mengumpulkan data yang disebarkan pada responden terpilih. Data dikumpulkan dengan membagikan instrumen penelitian berupa kuesioner yang diberikan kepada responden terpilih. Setiap instrumen disusun dari beberapa butir pertanyaan atau pernyataan dimana responden akan memberikan penilaian setiap butir pertanyaan atau pernyataan dengan menggunakan skala Likert. Teknik analisis data yang digunakan dalam penelitian ini meliputi analisis statistik deskriptif, pengujian kualitas data berupa uji validitas dan reliabilitas, pengujian asumsi klasik berupa pengujian normalitas, multikolinieritas, dan heteroskedestisitas serta yang terakhir yakni pengujian hipotesis berupa analisis regresi berganda, uji koefisien determinasi (Adjusted $R_{2}$ ), dan uji t.

\section{Hasil dan Pembahasan}

Sejumlah 168 kuesioner disebarkan dan yang kembali sebanyak 166 atau 99\%, yang disebabkan karena terdapat dua responden yang tidak mengisi kuesioner sehingga hanya 166 kuesioner yang bisa dianalisis. Analisis statistik deskriptif mendapatkan hasil bahwa variabel religiusitas $(X 1)$ bernilai minimum 20 , maksimum 30 , serta rerata senilai 25,37 dengan standar deviasi (SD) senilai 2,45. Variabel integritas (X2) bernilai minimum 28, maksimum 40, serta rerata senilai 34,15 dengan SD senilai 3,57 . Variabel penegakan peraturan (X3) bernilai minimum 16, maksimum 25, serta rerata senilai 20,99 dengan SD 
senilai 2,14. Variabel fraud pada pengelolaan keuangan desa $(Y)$ bernilai minimum 15, maksimum 29, dan rerata senilai 21,87 dengan SD senilai 3,14.

Uji kualitas data dilakukan untuk mengetahui apakah data yang sudah dikumpulkan melalui kuesioner bisa menunjukkan konsep pengujian secara tepat. Pengujian validitas serta reliabilitas termasuk dalam uji kualitas. Validitas diuji melalui hitungan keterkaitan antara nilai per butir pernyataan dengan keseluruhan nilai. Teknik korelasi Pearson's Correlation digunakan dalam pengujian validitas dengan bantuan program SPSS 24.0 for Windows. Menurut Gozali (2011), kriteria keputusan valid suatu pernyataan dinyatakan apabila nilai signifikansi (Sig.) $<\alpha=0,05$. Hasil setelah diuji menunjukkan bahwa nilai Sig. lebih kecil dari $\alpha=0,05$ maka seluruh butir pernyataan dikategorikan valid pada kuesioner religiusitas $\left(X_{1}\right)$, integritas $\left(X_{2}\right)$, penegakan peraturan $\left(X_{3}\right)$,dan fraud pada pengelolaan keuangan desa $(\mathrm{Y})$.

Uji reliabilitas ditujukan untuk mengetahui konsistensi perolehan jawaban responden. Menurut (Ghozali, 2011), kriteria keputusan reliabel dinyatakan apabila Cronbach Alpha lebih dari 0,70 . Setelah diuji, dapat dilihat adanya Cronbach Alpha diatas 0,70 pada semua variabel sehingga dikategorikan reliabel yang berarti adanya perolehan data atau jawaban yang konsisten pada tiap butir pernyataan sehingga adanya kemiripan antara perolehan jawaban dengan jawaban sebelumnya.

Apabila pengujian kualitas data telah terpenuhi, metode analisis data selanjutnya adalah uji asumsi klasik digunakan untuk mengetahui apakah data yang diperoleh dari responden melalui kuesioner dapat dianalisis menggunakan model regresi atau tidak. Uji normalitas dengan One Sample Kolmogorov-Smirnov Test, uji multikolinieritas, dan uji heteroskedastisitas masuk ke dalam pengujian asumsi klasik penelitian ini. Menurut (Ghozali, 2011), terdistribusinya data secara normal apabila Sig. mempunyai nilai di atas 0,05 . Berdasarkan hasil uji normalitas yang telah dilakukan menunjukkan bahwa nilai Kolmogorov Smirnov sebesar 0,064 dengan nilai Sig. sebesar 0,095 sehingga dapat ditarik kesimpulan bahwa data-data diperoleh melalui kuesioner telah berdistribusi secara normal dan model penelitian ini memenuhi pengujian asumsi klasik normalitas.

Keberadaan hubungan antara satu variabel bebas (independen) dengan yang lainnya dapat diketahui melalui pengujian multikolinieritas. Besarnya Variance Inflation Factor (VIF) serta nilai tolerance menjadi tolak ukur terjadinya multikolinieritas atau tidak (Ghozali, 2011). Ketika VIF melebihi 10 atau tolerance bernilai di bawah 0,10 maka disanalah terjadi multikolinieritas. Hasil pengujian multikolinieritas menunjukkan bahwa setiap variabel independen bernilai VIF di bawah 10 serta tolerance yang melebihi 0,10 yang berarti antar variabel independen tidak terbentuknya gejala multikolinieritas.

Munculnya perbedaan varians satu residual dari satu pengamatan ke pengamatan lain dapat diketahui melalui pengujian heteroskedastisitas (Ghozali, 2011). Uji Glejser digunakan untuk mengetahui ada tidaknya heteroskedastisitas. Jika nilai signifikansi $>0,05$ maka terjadi homoskedastisitas, akan tetapi jika sebaliknya nilai signifikansi $<0,05$ maka terdapat heteroskedastisitas. Hasil pengujian heteroskedastisitas memperlihat adanya signifikansi melebihi 0, 05 yang terbentuk antara variabel independen yang berarti tidak munculnya gejala heteroskedastisitas pada model regresi yang digunakan.

Analisis1regresi linier berganda dipilih sebagai pengujian hipotesis yang ada sehingga permasalahan-permasalahan yang telah dirumuskan dapat dipecahkan untuk mengetahui adanya pengaruh pada dua variabel atau lebih. Setelah diuji melalui analisis konstanta dan koefisien beta, diperoleh persamaan garis regresi sebagai berikut:

Tabel 1.

Hasil Analisis Koefisien Beta dan Uji t

\begin{tabular}{|c|c|c|c|c|c|c|}
\hline & \multirow[t]{2}{*}{ Model } & \multicolumn{2}{|c|}{$\begin{array}{l}\text { Unstandardized } \\
\text { Coefficients }\end{array}$} & \multirow{2}{*}{$\begin{array}{c}\text { Standardized } \\
\text { Coefficients } \\
\text { Beta }\end{array}$} & \multirow[t]{2}{*}{$T$} & \multirow[t]{2}{*}{ Sig. } \\
\hline & & $B$ & Std. Error & & & \\
\hline \multirow[t]{4}{*}{1} & (Constant) & 51,334 & 1,450 & & 35,412 & 0,000 \\
\hline & $X_{1}$ & $-0,280$ & 0,073 & $-0,218$ & $-3,826$ & 0,000 \\
\hline & $x_{2}$ & $-0,431$ & 0,055 & $-0,491$ & $-7,874$ & 0,000 \\
\hline & $x_{3}$ & $-0,364$ & 0.088 & -0.249 & $-4,152$ & 0,000 \\
\hline
\end{tabular}


Berdasarkan perhitungan regresi linier berganda yang ditunjukkan pada tabel di atas, maka didapatkan hasil persamaan sebagai berikut.

$Y=51,334-0,280 X 1-0,431 X 2-0,364 X 3+\varepsilon$

Terbentuknya model regresi tersebut menginterpretasikan :

a. Apabila terbentuk konstanta senilai 51,334 , berarti variabel religiusitas $\left(X_{1}\right)$, integritas $\left(X_{2}\right)$, dan penegakan peraturan $\left(X_{3}\right)$ bernilai konstan $(0)$, maka variabel fraud pada pengelolaan keuangan desa $(Y)$ memiliki nilai 51,334 satuan.

b. Adanya pengaruh negatif antara variabel religiusitas $\left(X_{1}\right)$ pada variabel fraud pengelolaan keuangan desa $(Y)$ secara negatif bisa diketahui melalui variabel religiusitas $\left(X_{1}\right)$ berkoefisien regresi $-0,280$. Ini mengindikasikan terjadinya penurunan sebanyak 0,280 satuan pada variabel fraud pada pengelolaan keuangan desa ( $Y$ ) apabila terjadi peningkatan 1 satuan variabel religiusitas $\left(X_{1}\right)$ dengan berasumsikan konstannya variabel independen lain.

c. Adanya pengaruh negatif antara variabel integritas $\left(X_{2}\right)$ pada variabel fraud pengelolaan keuangan desa $(Y)$ secara negative bisa diketahui melalui variabel integritas $\left(X_{2}\right)$ berkoefisien regresi $-0,431$. Ini mengindikasikan terjadinya penurunan sebanyak $-0,431$ satuan pada variabel fraud pada pengelolaan keuangan desa $(Y)$ apabila terjadi peningkatan 1 satuan variabel integritas $\left(X_{2}\right)$ dengan berasumsikan konstannya variabel independen lain.

d. Adanya pengaruh negatif antara variabel penegakan peraturan $\left(X_{3}\right)$ pada variabel fraud pengelolaan keuangan desa $(Y)$ secara negatif bisa diketahui melali variabel penegakan peraturan $\left(X_{3}\right)$ berkoefisien regresi $-0,364$. Ini mengindikasikan terjadinya penurunan sebanyak 0,364 satuan pada variabel fraud pada pengelolaan keuangan desa $(\mathrm{Y})$ apabila terjadi peningkatan 1 satuan variabel penegakan peraturan $\left(\mathrm{X}_{3}\right)$ dengan berasumsikan konstannya variabel independen lain.

Melalui koefisien determinasi (Adjusted $\mathrm{R}_{2}$ ) dapat diperkirakan tingkat kemampuan model dalam menjelaskan variasi variabel dependen (Ghozali, 2011). Hasil analisis koefisien determinasi menunjukkan bahwa nilai Adjusted R Square sebesar 0,727 atau 72,7\%. Hal ini berarti bahwa variabel religiusitas $\left(X_{1}\right)$, integritas $\left(X_{2}\right)$, dan penegakan peraturan $\left(X_{3}\right)$ hanya mampu menjelaskan $72,7 \%$ variasi variabel fraud pada pengelolaan keuangan desa $(Y)$. Sementara sisa $27,3 \%$ merupakan pengaruh yang diberikan variabel lain di luar penelitian yang dapat mempengaruhi fraud pengelolaan keuangan desa. Berikut akan tersaji hasil analisis koefisien determinasi penelitian:

Tabel 2.

Hasil Analisis Koefisien Determinasi

\begin{tabular}{ccccc}
\hline Model & $\mathrm{R}$ & $\mathrm{R}$ Square & $\begin{array}{c}\text { Adjusted } \mathrm{R} \\
\text { Square }\end{array}$ & $\begin{array}{c}\text { Std. Error of the } \\
\text { Estimate }\end{array}$ \\
\hline 1 & 0,856 & 0,732 & 0,727 & 1,637 \\
\hline
\end{tabular}

Sumber: Output SPSS 24.0 for Windows

Melalui pengujian hipotesis secara individu (uji t), dapat ditunjukkan tingkat pengaruh variabel independen pada variabel dependen dengan berasumsikan konstannya variabel lain. Ditinjau dari Tabel 1, signifikansi uji t variabel religiusitas $\left(X_{1}\right)$ bernilai $0,000<0,05$ serta berkoefisien negatif 0,280 maka $\mathrm{H}_{1}$ diterima. Tabel tersebut juga menggambarkan signifikansi uji t variabel integritas $\left(X_{2}\right)$ bernilai $0,000<0,05$ serta berkoefisien negatif 0,431 maka $\mathrm{H}_{2}$ diterima. Variabel penegakan peraturan $\left(\mathrm{X}_{3}\right)$ juga dapat diketahui signifikansi uji $\mathrm{t}$ nya bernilai $0,000<0,05$ serta berkoefisien negatif 0,364 maka $\mathrm{H} 3$ diterima.

\section{Pengaruh Religiusitas terhadap Fraud pada Pengelolaan Keuangan Desa}

Ditinjau dari hasil pengujian, bisa dilihat religiusitas berpengaruh negatif dan signifikan terhadap fraud pada pengelolaan keuangan desa di Kabupaten Buleleng. Hal ini dapat dilihat dari hasil analisis regresi linier berganda yang membuat variabel religiusitas $\left(X_{1}\right)$ berkoefisien negatif $-0,280$ mengindikasikan timbulnya pengaruh negatif diantara variabel 
religiusitas $\left(X_{1}\right)$ pada variabel fraud pengelolaan keuangan desa $(Y)$. Signifikansi uji t variabel religiusitas $\left(X_{1}\right)$ bernilai 0,000 yang berada di bawah 0,05 berarti variabel fraud pada pengelolaan keuangan desa $(Y)$ dipengaruhi oleh variabel religiusitas $\left(\mathrm{X}_{1}\right)$ secara signifikan. Regresi linier berganda yang dianalisis serta uji t mengindikasikan peningkatan religiusitas seorang perangkat desa mengakibatkan penurunan tingkat fraud. Sebaliknya, apabila seorang perangkat desa memiliki tingkat religiusitas yang rendah maka kecenderungan untuk melakukan fraud akan semakin meningkat.

Nilai-nilai agama akan dipegang teguh prinsipnya oleh mereka yang tingkat religiusitasnya tinggi sehingga perilaku yang dapat merugikan diri sendiri dan orang lain pun dapat dicegah. Perangkat desa yang memiliki sikap religiusitas tinggi tidak akan melakukan tindakan menyimpang seperti fraud saat menjalankan tugas sebagai pihak yang diberi kepercayaan untuk mengelola keuangan desa. Sikap religiusitas setiap individu akan mengendalikan tingkah laku agar senantiasa dapat bersikap lebih bijak dalam mengambil sebuah keputusan dan bertindak sebagai mana mestinya. Aktivitas keagamaan seperti menunaikan ibadah sesuai keyakinan masing-masing diharapkan bisa mendorong peningkatan akhlak serta religiusitas tiap individu sehingga niat untuk bertindak negatif seperti melakukan kecurangan atau fraud bisa dihindari.

Hasil penelitian ini juga didukung oleh penelitian-penelitian sebelumnya yang memaparkan terkait kecenderungan fraud bisa dipengaruhi oleh religiusitas secara negatif dan signifikan (Herlyana et al., 2017); (Egita, 2018); (K. Y. D. Dewi et al., 2018)

\section{Pengaruh Integritas Terhadap Fraud pada Pengelolaan Keuangan Desa}

Ditinjau dari hasil pengujian, dapat diketahui fraud pada pengelolaan keuangan desa di Kabupaten Buleleng dipengaruhi secara negatif serta signifikan oleh integritas. Ini ditunjukkan melalui hasil analisis regresi linier berganda yang membuat variabel integritas $\left(X_{2}\right)$ berkoefisien negatif -0,431 mengindikasikan timbulnya pengaruh negatif diantara variabel integritas $\left(\mathrm{X}_{2}\right)$ pada variabel fraud pengelolaan keuangan desa $(\mathrm{Y})$. Signifikansi uji $t$ variabel integritas $\left(X_{2}\right)$ bernilai 0,000 yang berada di bawah 0,05 berarti variabel fraud pada pengelolaan keuangan desa $(\mathrm{Y})$ dipengaruhi oleh variabel integritas $\left(\mathrm{X}_{2}\right)$ secara signifikan. Regresi linier berganda yang dianalisis serta uji t mengindikasikan peningkatan integritas seseorang perangkat desa mengakibatkan penurunan tingkat fraud. Sebaliknya, apabila seorang perangkat desa memiliki tingkat integritas yang rendah maka peningkatan posibilitas terjadinya fraud akan terjadi.

Integritas menggambarkan sikap individu berlandaskan prinsip kejujuran dan berterus terang. Jika seseorang memiliki sikap integritas tinggi, maka ia tidak mudah bertindak curang yang membuat pihak lain merasa dirugikan. Begitu pula ketika keuangan desa dikelola oleh perangkat atau aparatur pemerintah desa, mereka yang berintegritas tinggi akan selalu bersikap berlandaskan prinsip kejujuran dalam menjalankan tugas.

Penelitian-penelitian sebelumnya juga menemukan hal yang sama yakni kecurangan akuntansi (fraud) cenderung terjadi karena dipengaruhi secara negative oleh integritas (Lestari dan Supadmi, 2017; Dewi dan Ratnadi, 2017; Apriliana dan Budiarto, 2018; Mujianingrum, 2019).

\section{Pengaruh Penegakan Peraturan Terhadap Fraud pada Pengelolaan Keuangan Desa}

Setelah dilakukan pengujian, didapatkan hasil berupa pengaruh negatif yang diberikan oleh penegakan peraturan pada fraud pengelolaan1keuangan desa di1Kabupaten Buleleng secara signifikan. Hal ini dapat dilihat dari hasil analisis regresi linier berganda yang mendapatkan hasil koefisien regresi variabel penegakan peraturan $\left(X_{3}\right)$ sebesar $-0,364$ menunjukkan bahwa terdapat pengaruh negatif antara variabel penegakan peraturan (X3) terhadap variabel fraud pada pengelolaan keuangan desa $(Y)$. Nilai signifikansi uji t variabel penegakan peraturan $\left(X_{3}\right)$ sebesar 0,000 dimana nilai tersebut lebih kecil dari 0,05 maka variabel penegakan peraturan $\left(X_{3}\right)$ mempunyai pengaruh signifikan terhadap variabel fraud pada pengelolaan keuangan desa $(\mathrm{Y})$. Regresi linier berganda yang dianalisis serta uji $t$ mengindikasikan semakin tegaknya peraturan maka fraud akan mengalami penurunan. 
Sebaliknya, apabila penegakan peraturan tidak dilakukan dengan baik maka orang akan semakin cenderung bertindak curang.

Semakin baik penegakan peraturan pada sebuah organisasi pemerintah desa, dapat menekan jumlah kecurangan atau fraud maka semua pihak dalam organisasi diwajibkan untuk mengikuti peraturan yang berlaku. Penegakan peraturan yang baik dapat mendukung kegiatan-kegiatan organisasi pemerintah desa yang berhubungan dengan kepentingan masyarakat dimana hal tersebut akan berpengaruh terhadap kinerja organisasi sehingga organisasi mampu memberikan pelayanan dan informasi yang diperlukan oleh pihak yang berkepentingan. Peraturan harus ditegakkan dengan baik dan melibatkan peran dari setiap komponen agar dapat meminimalisir pelanggaran-pelanggaran yang dilakukan oleh perangkat desa, termasuk pelanggaran atau kecurangan dalam mengelola uang desa.

Bersesuaian dengan perolehan hasil penelitian ini, (Didi dan Indra Cahya Kusuma, 2018), (Budiartini, 2019) juga mendapati hal yang serupa yakni adanya pengaruh negative dan signifikan dari penegakan peraturan pada kecenderungan fraud.

\section{Simpulan dan Saran}

Berdasarkan hasil pengujian dan pembahasan yang telah dipaparkan, maka dapat disimpulkan bahwa: (1) Fraud pada pengelolaan keuangan desa di Kabupaten Buleleng dipengaruhi secara negatif dan signifikan oleh tingkat religiusitas seseorang. Apabila semakin tinggi tingkat religiusitas maka fraud saat mengelola uang desa akan mengalami penurunan. Sebaliknya, apabila semakin rendah tingkat religiusitas maka peningkatan fraud pun akan terjadi, (2) Fraud pada pengelolaan keuangan desa di Kabupaten Buleleng dipengaruhi secara negatif dan signifikan oleh integritas perangkat desa. Tingginya integritas mereka akan menurunkan kecenderungan terjadinya fraud saat mengelola keuangan desa. Sebaliknya, apabila tingkat integritas rendah maka fraud pun akan meningkat, (3) Fraud pada pengelolaan keuangan desa di Kabupaten Buleleng dipengaruhi secara negative dan signifikan oleh penegakan peraturan. Semakin tegaknya peraturan dalam mengelola uang desa, maka fraud akan mengalami penurunan. Sebaliknya, apabila penegakan peraturan tidak dilakukan dengan baik maka orang akan semakin cenderung bertindak curang.

Adapun saran yang dapat disampaikan bagi Pemerintah Desa yaitu melalui penelitian ini diharapkan perangkat pemerintah desa dapat meningkatkan kualitas religiusitas berdasarkan agama dan kepercayaan yang dianut dengan lebih memahami arti pentingnya nilai-nilai agama untuk dijadikan pedoman dalam bersikap agar segala tindakan yang dilakukan dapat dikendalikan dan tidak memiliki niat melakukan perbuatan yang bersifat negative, melalui penelitian ini diharapkan perangkat pemerintah desa dapat meningkatkan kualitas integritas dengan lebih berani dalam menghadapi tekanan atau kesulitan yang dapat mempengaruhi sikap dan pendapatnya. Integritas sangat diperlukan bagi tiap individu agar mampu bersikap lebih baik dan bijaksana serta dapat mempertimbangkan segala hal sebelum mengambil keputusan, dan melalui penelitian ini diharapkan pimpinan dalam pemerintah desa atau pihak yang memiliki jabatan lebih tinggi tetap menjaga dan meningkatkan penegakan peraturan seperti tanggung jawab setiap perangkat desa lebih ditingkatkan lagi serta melakukan pengawasan dan mengontrol kinerja perangkat desa sehingga aktivitas operasional dapat berjalan dengan lancar dan efektif. Sedangkan Bagi Peneliti Selanjutnya adapun saran yang disampaikan yaitu berdasarkan hasil penelitian pada koefisien determinasi menunjukkan bahwa $72,7 \%$ fraud pada pengelolaan keuangan desa dipengaruhi oleh variabel religiusitas, integritas, dan penegakan peraturan, sementara $27,3 \%$ dipengaruhi oleh faktor luar. Disarankan agar peneliti berikutnya memasukkan variabelvariabel yang diduga memiliki pengaruh terhadap fraud pada pengelolaan keuangan desa seperti sifat love of money (kecintaan seseorang akan uang), sifat machiavellian (persepsi tentang hubungan antar personal), komitmen organisasi, dan lainnya, dan diharapkan agar memperluas responden dengan melibatkan seluruh perangkat yang ada di desa dan memperluas wilayah penelitian seperti melakukan penelitian pada desa di luar Kabupaten Buleleng sehingga penelitian dapat digeneralisasikan dan hasil penelitian akan menjadi lebih baik dan disarankan agar peneliti selanjutnya menggunakan metode pengumpulan data melalui wawancara sehingga informasi yang diperoleh lebih lengkap dan akurat. 


\section{Daftar Rujukan}

Afsari, S. F. (2017). Analisis Faktor-Faktor yang Mempengaruhi Kecenderungan Kecurangan/Fraud di Sektor Pemerintahan Berdasarkan Teori Fraud Triangle: Persepsi Pegawai Pemerintahan (Studi pada SKPD di Kabupaten Jember) [Universitas Jember]. http://repository.unej.ac.id/handle/123456789/78631

Aida, F. N. (2017). Pengaruh Religiusitas Terhadap Locus Of Control-Internal Pada Siswa Sma Nu Al-Munawir Gringsing Kabupaten Batang. Skripsi.Universitas Islam Negeri

Aini, N., Prayudi, M. A., \& Diatmika, P. G. (2017). Pengaruh Perspektif Fraud Diamond Terhadap Kecenderungan Terjadinya Kecurangan (Fraud) Dalam Pengelolaan Keuangan Desa (Studi Empiris Pada Desa Di Kabupaten Lombok Timur). E-Jurnal Akuntansi Universitas Pendidikan Ganesha, Vol. 8, No.2

Bali Editor. (2019). Diduga Terjadi Penyalahgunaan Dana APBDes Hampir Rp 1 M di Desa Tirtasari. https://balieditor.com/diduga-terjadi-penyalahgunaan-dana-apbdes-hampir-rp1-m-di-desa-tirtasari/. Diakses tanggal 17 Januari 2020

Budiartini, K. (2019). Faktor-Faktor yang Mempengaruhi Terjadinya Kecurangan Akuntansi dalam Perspektif Fraud Diamond (Studi Empiris pada Bank Perkreditan Rakyat (BPR) Kabupaten Buleleng). JIMAT (Jurnal IImiah Mahasiswa Akuntansi), Vol.10, No.2

Candra, P. (2019). Terbukti Korupsi, Mantan Perbekel Celukan Bawang Buleleng Divonis 15 Bulan Penjara. Tribun Bali.Com. https://bali.tribunnews.com/2019/12/18/terbuktikorupsi-mantan-perbekel-celukan-bawang-buleleng-divonis-15-bulan-penjara.

Diakses tanggal 17 Januari 2020

Dewi, K. Y. D., Dewi, P. E. D. M., \& Sujana, E. (2018). Pengaruh bystander effect, whistleblowing, asimetri informasi dan religiusitas terhadap kecenderungan kecurangan pada badan usaha milik desa (BUMDES) di kecamatan Busungbiu. JIMAT (Jurnal Ilmiah Mahasiswa Akuntansi), $\quad$ Vol. 9, $\quad$ No. 2 https://doi.org/10.1017/CBO9781107415324.004

Dewi, K. Y. K. dan N. M. D. R. (2017). Pengaruh Pengendalian Internal dan Integritas pada Kecenderungan Kecurangan Akuntansi Satuan Kerja Perangkat Daerah Kota $\begin{array}{llll}\text { Denpasar. E-Jurnal Akuntansi, } & \text { Nol.18, }\end{array}$ https://ojs.unud.ac.id/index.php/Akuntansi/article/view/21131

Didi dan Indra Cahya Kusuma. (2018). Faktor-Faktor yang Berpengaruh Terhadap Kecenderungan Kecurangan (Fraud): Persepsi Pegawai Pemerintahan Daerah Kota Bogor (Determinants of Fraudulent Tendencies: Perception from Employees of Government Agencies in the City of Bogor). Jurnal Akuntansi Dan Keuangan Indonesia, Vol.15, No.1 https://doi.org/http://dx.doi.org/10.21002/jaki.2018.01

Egita, E. dan S. M. (2018). Pengaruh Kesesuaian Kompensasi, Reward and Punishment, dan Religiusitas Terhadap Fraud (Studi pada Karyawan BMT di Kabupaten Wonosobo). Jurnal Ekonomi, Bisnis, Dan Akuntansi (JEBA), Vol.20, No.1

Ghozali, I. (2011). Aplikasi Analisis Multivariate dengan Program IBM SPSS 19. Edisi 5 (Edisi 5). Badan Penerbit Universitas Diponegoro.

Herlyana, M. V., S1ujana, E., \& Prayudi, M. A. (2017). Pengaruh Religiusitas dan Spiritualitas terhadap Kecurangan Akademik Mahasiswa [Studi empiris pada Mahasiswa Universitas Pendidikan Ganesha Singaraja]. Jurnal Akuntansi Program S1, Vol. 8 No.2. https://doi.org/http://dx.doi.org/10.23887/jimat.v8i2.13313 
Kumparan. (2019). 3 Kasus Korupsi di Buleleng dan Denpasar Disidik Kejati Bali. Kumparan. https://doi.org/https://kumparan.com/kanalbali/3-kasus-korupsi-di-buleleng-dandenpasar-disidik-kejati-bali-1sPbem8q342. Diakses tanggal 17 Januari 2020.

Lestari, N. K. L., \& Supadmi, N. L. (2017). Pengaruh Pengendalian Internal, Integritas dan Asimetri Informasi pada Kecurangan Akuntansi. E-Jurnal Akuntansi, Vol.21, No.1

Mujianingrum, A. (2019). Pengaruh Pengendalian Internal, Integritas, dan Asimetri Informasi pada Kecurangan Akuntansi: Studi pada Desa-desa di Kecamatan Miri Kabupaten Sragen [Institut Agama Islam Negeri Surakarta]. https://doi.org/http://eprints.iainsurakarta.ac.id/id/eprint/4156

Pamungkas, I. D. (2014). Pengaruh Religiusitas dan Rasionalisasi dalam Mencegah dan Mendeteksi Kecenderungan Kecurangan Akuntansi. Jurnal Ekonomi Dan Bisnis, Vol. 15, No.2 